\title{
PENGARUH METODE STUDENT TEAMS-ACHIEVEMENT DIVISION (STAD) DAN PROBLEM BASED LEARNING TERHADAP HASIL BELAJAR DITINJAU DARI POTENSI AKADEMIK SISWA SMK OTOMOTIF
}

\author{
Aci Primartadi \\ Program Pascasarajana Universitas Yogyakarta \\ aci.primartadi@gmail.com
}

\begin{abstract}
Abstrak: Pengaruh Metode Student Teams-Achievement Division (STAD) dan Problem Based Learning terhadap Hasil Belajar Ditinjau dari Potensi Akademik Siswa SMK Otomotif. Penelitian ini bertujuan untuk menguji: (1) pengaruh metode pembelajaran Student Teams-Achievement Divitions (STAD) terhadap peningkatan hasil belajar ditinjau dari potensi akademik siswa, (2) pengaruh metode pembelajaran Problem Based Learning terhadap peningkatan hasil belajar ditinjau dari potensi akademik siswa, dan (3) interaksi antara metode pembelajaran dan potensi akademik siswa dalam pengaruhnya terhadap pencapaian hasil belajar. Penelitian ini merupakan penelitian eksperimen semu (quasi-experimental research) dengan desain faktorial yang dilakukan dengan memberikan perlakuaan dalam metode pembelajaran. Pada penelitian ini menggunakan dua kelas sebagai sampel dan kedua kelas tersebut diberikan pembelajaran dengan menggunakan dua metode berbeda. Satu kelas menggunakan metode STAD, sedangkan kelas yang lainnya diberikan metode PBL. Untuk variabel bebas yang lain yaitu variabel atribut potensi akademik siswa dijadikan sebagai variabel yang ikut mempengaruhi variabel terikat. Rancangan yang digunakan dalam penelitian ini menggunakan desain faktorial $2 \times 2$. Penelitian ini menggunakan sampel dengan jumlah 52 siswa dengan kelompok STAD 25 siswa dan kelompok PBL 27 siswa. Teknik analisis data dalam penelitian ini menggunakan analisis varian (ANAVA) dengan progam SPSS 18. Hasil penelitian menunjukkan bahwa: (1) terdapat interaksi antara metode pembelajaran dengan potensi akademik siswa dan pengaruhnya terhadap pencapaian hasil belajar siswa, (2) secara keseluruhan tidak terdapat perbedaan hasil belajar antara siswa yang diajar dengan metode pembelajaran Student Teams-achievement Division STAD dan metode pembelajaran Problem Based Learning, (3) secara keseluruhan terdapat perbedaan hasil belajar antara siswa yang mempunyai kemampuan potensi akademik tinggi dan rendah, (4) tidak terdapat perbedaan hasil belajar siswa yang diajar dengan metode Student Teams-achievement Division STAD antara siswa yang mempunyai kemampuan potensi akademik tinggi dan rendah, (5) terdapat perbedaan hasil belajar siswa yang diajar dengan metode Problem Based Learning antara siswa yang mempunyai kemampuan potensi akademik tinggi dan rendah.
\end{abstract}

Kata kunci: pengaruh, metode pembelajaran, potensi akademik

\section{THE INFLUENCE OF METHOD OF STUDENT TEAMS-ACHIEVEMENT DIVISION (STAD) AND PROBLEM BASED LEARNING ON LEARNING OUTCOMES VIEWED FROM ACADEMIC POTENTIAL STUDENTS OF SMK AUTOMOTIVE}

\begin{abstract}
The Influence of Method of Student Teams-Achievement Division (STAD) and Problem Based Learning on Learning Outcomes Viewed from Academic Potential Students of SMK Automotive. This study aims to examine: (1) the influence of teaching methods Student TeamsAchievement Divitions (STAD) for improvement learning outcomes viewed from academic potential students, (2) the influence of teaching methods Problem Based Learning for improvement learning outcomes viewed from academic potential students, and (3) the interaction between teaching methods and the academic potential students and its effects on the students learning outcomes. This study was a quasi experimental with factorial design study conducted by giving treatments in the learning method. In
\end{abstract}


this research using two-class and the second class as a sample is given of learning by using two different methods. One class of STAD method, whereas the other classes given PBL method. For the other independent variables are the academic potential students attribute variables used as variables that influence the dependent variable. The research designed employed in this study was a $2 \times 2$ factorial design. This study involved a sample consisting of 52 students, divided into the STAD group (25 students) and the PBL group (27 students). The data were analyzed by means of the analysis of variance (ANOVA) using the SPSS 18 program. The results of the study were as follows: (1) there is a interaction between the method of learning with academic potential students and its effect on student achievement, (2) On the whole, there is no difference between the learning outcomes of students taught with the learning method Student Teams-Achievement Division STAD and Problem Based learning, (3) On the whole, there are differences in learning outcomes between students who have academic potential ability of high and low, (4) there is no difference in learning outcomes of students who were taught by the method of student Teams-achievement Division STAD between students who have the academic potential ability high and low, (5) there are differences in learning outcomes of students who were taught by the method of Problem Based learning between students who have the academic potential ability high and low.

Keywords: Influence, Teaching methods, Academic Potential

\section{PENDAHULUAN}

Sebagai bagian dari sistem pendidikan nasional, Sekolah Menengah Kejuruan (SMK) merupakan pendidikan pada jenjang menengah yang menyiapkan peserta didiknya untuk memasuki dunia kerja. Tidak hanya kebutuhan dalam belajar di sekolah, tetapi kualitas lulusan Sekolah Menengah Kejuruan (SMK) di dunia kerja menjadi tolok ukur keberhasilan pelaksanaan proses pendidikan kejuruan. Seperti yang di ungkapkan Finch (1999: 14):

The ultimate success of a vocational and technical curriculum is not measured merely through student educational achievement but through the result of that achievement-result that take the form of permormance in the work world. Thus, the vocational and technical curriculum is oriented toward process (experience and activities within the school setting) and product (effect of these experiences and activities on former student).

Dari paparan tersebut dapat disimpulkan bahwa keberhasilan utama kurikulum kejuruan dan teknis tidak diukur hanya melalui prestasi siswa pendidikan tetapi melalui hasil yang menghasilkan prestasi dalam bentuk kinerja lulusan di dunia kerja. Dengan demikian, kurikulum Sekolah Menengah Kejuruan berorientasi pada proses (pengalaman dan kegiatan dalam lingkungan sekolah) dan produk (efek dari pengalaman-pengalaman dan kegiatan siswa).

Siswa Sekolah Menengah Kejuruan (SMK) diharapkan mempunyai bakat dan kemampuan akademik yang memadai sehingga dalam proses pembelajaran dapat menjadi pribadi yang kreatif dan berwawasan. Pada kenyataannya siswa mempunyai bakat dan kemampuan akademik yang berbeda beda, dengan perbedaan inilah maka perlu diberikan perlakuan yang berbeda pula pada masing masing siswa. Bakat dan kemampuan siswa dapat diukur.Tes yang biasa digunakan dalam pengukuran bakat dan kemampuan ini adalah Tes Potensi Akademik (TPA). Saat ini, banyak lembaga pendidikan yang menyelenggarakan Tes Potensi Akademik (TPA) dalam penerimaan peserta didik baru untuk mengukur bakat dan kemampuan khususnya dalam bidang akademis 
sehingga diharapan dapat menyeleksi dan mendapatkan siswa yang berkualitas.

Berdasarkan hasil survey yang telah dilakukan peneliti pada bulan Oktober 2011, dapat dilihat bahwa Pembelajaran di SMK Pembaharuan Purworejo selama ini masih kurang memperhatikan kemampuan potensi akademik pada masing-masing siswa yang mempunyai kualitas dan memerlukan perlakuan yang berbeda dalam mengajar. Ini dapat dilihat dari cara mengajar guru yang masih konvensional dengan menggeneralisasikan seluruh peserta didik dan kebanyakan menggunakan metode ceramah. Siswa yang mempunyai kemampuan dan bakat akademik yang baik, kemungkinan masih bisa mengikuti proses pembelajaran walaupun kurang maksimal, namun bagaimana dengan siswa yang mempunyai kemampuan dan bakat akademik kurang baik, tentunya akan lebih sulit mengikuti proses pembelajaran.

Keberhasilan proses pendidikan di sekolah tidak hanya ditentukan oleh guru dan siswa, tetapi juga pemilihan metode pembelajaran yang tepat. Menurut Dittrich et al. (2009: 17), dalam proses pembelajaran guru dituntut menjadi social worker, psychologist, mediator,communicator, team worker, knowledge networker, dan an expert. Salah satu metode pembelajaran yang mendekati konsep ini diantaranya adalah model pembelajaran kooperatif (cooperative learning). Metode cooperative learning menekankan pada diskusi atau kerjasama serta memungkinkan siswa untuk saling bertukar gagasan dan ide dalam kelompok, sehingga dalam prosesnya siswa akan menjadi lebih aktif. Hal tersebut sesuai dengan yang diungkapkan Slavin (1995:5) :

All cooperative learning methods share the idea that students work together to learn and are responsible for their team-mates' learning as well as their own. These methods emphasise the use of team goals and team success which can be achieved only if all members of the team learn the objectives being taught.

Jenis metode pembelajaran kooperatif mempunyai berbagai model. Namun dari berbagai model pembelajaran kooperatif tersebut yang dirasa paling tepat bagi siswa dalam pembelajaran ditinjau dari kemampuan potensi akademik menurut peneliti adalah Student Team Achievement Division (STAD). Dalam pembelajaran kooperatif model STAD akan memberikan kesempatan kepada siswa untuk berdiskusi dalam kelompok kelas sehingga akan tercipta suasana belajar yang lebih aktif, efektif dan menyenangkan.

Selain cooperative learning, metode lain yang sesui digunakan untuk peningkatan hasil belajar menurut peneliti adalah metode Problem Based Learning (PBL). Metode $P B L$ adalah pembelajaran dengan berbasis masalah. Dalam metode pembelajaran ini masalah dapat diperoleh dari lapangan atau pengalaman dari siswa, selain itu masalah juga bisa didapatkan dari ketidak tahuan siswa akan kompetensi yang akan diajarkan. Setalah masalah diperoleh maka selanjutnya melakukan perumusan masalah, dari masalah masalah tersebut kemudian dipecahkan secara bersama sama dengan didiskusikan.

Dalam penerapanya, dari kedua metode tersebut tidak terlapas dari kemampuan potensi akademik siswa. Potensi akademik adalah kemempuan siwa dalam memahami sebuah 
materi serta mengembangkannya. Siswa yang memiliki bakat dan kemampuan akademik yang baik biasanya cukup cakap dalam proses pembelajaranya namun sebaliknya untuk siswa yang memiliki bakat dan kemampuan akademik yang rendah kurang mampu menerima materi dalam pembelajaran sehingga akan lebih sulit berkembang dan kurang mempunyai kreatifitas yang baik, Sehingga dalam penggunaan metode pembelajaran, guru harus melihat metode apakah yang paling tepat digunakan untuk siswa dengan kondisi kemampuan potensi akademik yang berbeda beda terutama dalam peningkatan hasil belajar yang lebih baik.

Sesuai dengan latar belakang di atas, penelitian ini bertujuan untuk menguji: (1) pengaruh metode pembelajaran Student TeamsAchievement Divitions (STAD) terhadap peningkatan hasil belajar ditinjau dari potensi akademik siswa, (2) pengaruh metode pembelajaran Problem Based Learning terhadap peningkatan hasil belajar ditinjau dari potensi akademik siswa, dan (3) interaksi antara metode pembelajaran dan potensi akademik siswa dalam pengaruhnya terhadap pencapaian hasil belajar.

\section{Hakikat Belajar}

Sugihartono

dkk

(2007:74)

mengemukakan bahwa belajar merupakan suatu proses perubahan tingkah laku sebagai hasil interaksi individu dan lingkunganya dalam memenuhi kebutuhan hidupnya. Sedangkan menurut Suyono dan Hariyanto (2011:9) mengemukakan bahwa belajar merupakan suatu aktivitas atau suatu proses untuk memperoleh pengetahuan, meningkatkan keterampilan, memperbaiki perilaku, sikap dan mengokohkan kepribadian. Pendapat itu diperkuat oleh Wina
Sanjaya (2007: 112) bahwa belajar merupakan proses perubahan tingkah laku akibat pengalaman dan latihan. Proses perubahan yang terjadi dalam diri seseorang tidak dapat disaksikan tetapi hanya dapat melihat dari gejala-gejala perubahan yang tampak. Sehingga, ketika ingin mengetahui perkembangan belajar sesorang dapat melihat perubahan tingkah laku seseorang.

\section{Penggunaan Strategi Pembelajaran}

Strategi pembelajaran adalah salah satu komponen yang menentukan perkembangan hasil belajar siswa. Sedangkan menurut Wina Sanjaya (2007:126) strategi pembelajaran merupakan perencanaan yang berisi tentang rangkaian kegiatan yang didesain untuk mencapai tujuan pendidikan tertentu. Strategi pengajaran merupakan keseluruhan dari metode dan prosedur yang menitikberatkan pada kegiatan siswa dalam proses belajar mengajar untuk mencapai tujuan yang telah ditentukan.

\section{Strategi Pembelajaran Kooperatif (Cooperative Learning)}

Cooperative learning berasal dari kata cooperative yang berarti mengerjakan sesuatu secara bersama sama dengan saling membantu satu sama lainya dalam satu kelompok. Slavin (1995:4) mengemukakan bahwa in cooperative learning metode student work together in fourmember teams to master material initially presented by the teacher. Ini berarti bahwa cooperative learning adalah suatu model pembelajaran dimana sistim belajar dan bekerjanya dalam kelompok yang berjumlah empat orang atau lebih secara kolaboratif untuk menguasai materi awalnya disajikan oleh guru 
sehingga dapat merangsang siswa lebih semangat dalam belajar.

\section{Student Teams- Achievement Divisions (STAD)}

Menurut Slavin (2010:144), dalam strategi pembelajaran tipe $S T A D$, siswa dikelompokan dalam tim-tim pembelajaran dengan anggota yang beragam dari kemampuan, jenis kelamin, ras dan etnis. Dalam menempatkan siswa dalam tim, jangan mengizinkan siswa memilih timnya mereka sendiri. Guru memperesentasikan pelajaran dan kemudian siswa bekerjasama tim untuk memastikan seluruh anggota tim telah menuntaskan pelajaran dengan baik. Pada akhirnya seluruh siswa memperoleh kuis individual tentang bahan ajar dan pada saat itu masing-masing individu tidak boleh saling membantu. Adapun penghargaan yang diberikan adalah penghargaan tim.

\section{Metode Pembelajaran model Problem Based Learning (PBL)}

Menurut Dutch (dalam Amir 2010:21) Problem-based learning merupakan metode instruksional yang menantang siswa agar belajar untuk belajar, bekerja sama dalam kelompok untuk mencari solusi bagi masalah yang nyata masalah ini diguakan untuk mengingatkan rasa keingintahuan serta kemampuan analitis dan inisiatif atas materi pelajaran. $P B L$ mempersiapkan siswa untuk berpikir kritis dan analisis dan untuk mencari dan menggunakan sumber pembelajaran yang sesuai. Sedangkan Menurut Glazer (2001) Problem-based learning is an instructional strategy in which students actively resolve complex problems in realistic situations. It can be used to teach individual lessons, units, or even entire curricula. PBL is often approached in a team environment with emphasis on building skills related to consensual decision making, dialogue and discussion, team maintenance, conflict management, and team leadership. Ini berarti bahwa pembelajaran berbasis masalah adalah strategi pembelajaran yang merangsang siswa aktif untuk memecahkan permasalahan dalam situasi nyata, pembelajaran tersebut bisa digunakan untuk mengajarkan pelajaran yang bersifat individu, unit, atau bahkan seluruh kurikulum.

\section{Potensi Akademik}

Menurut Ibnu Hajar (2010:125) bahwa tes potensi akademik merupakan teknik praktis dari sebuah wilayah yang lebih umum dari tes psikologi, dimana TPA secara spesifik lebih diarahkan kepada pengukuran kemampuan diwilayah akademik atau prestasi belajar. Hal tersebut diperkuat dalam http://episentrum.com/ artikel-psikologi/peran-dalam-pengukuran-danevaluasi dijelaskan bahwa Tes kesiapan pendidikan yang secara umum disebut dengan tes potensi akademik atau tes kemampuan belajar (academic scholastic aptitude) mempunyai kegunaan sama dengan tes intelegensi serta dapat dipakai mulai dari sekolah dasar hingga pascasarjana. Dari pendapat tersebut dapat disimpulkan bahwa tes potensi akademik merupakan cabang dari tes psikologis itu sendiri yang digunakan untuk mengukur kesiapan pendidikan yang dapat digunakan mulai dari sekolah dasar hinga jenjang pascasarjana. 


\section{METODE}

Penelitian ini bertujuan untuk menguji pengaruh metode pembelajaran Student Teamsachievement Division (STAD) dan Problem Based Learning (PBL) terhadap peningkatan hasil belajar pada kompetensi Memelihara/Servis sistem bahan bakar bensin ditinjau dari potensi akademik siswa. Sebelum dilakukan pembelajaran dilakukan Tes Potensi Akademik (TPA) dan menganalisisnya untuk mengetahui perbedaan kemampuan potensi akademik pada masing-masing siswa.

Penelitian ini adalah penelitian eksperimen semu (quasi-experimental research) dengan desain faktorial yang dilakukan dengan memberikan perlakuaan dalam metode pembelajaran. Pada penelitian ini menggunakan dua kelas sebagai sampel dan kedua kelas tersebut diberikan pembelajaran dengan menggunakan dua metode berbeda. Satu kelas menggunakan metode Student Teamsachievement Division (STAD), sedangkan kelas yang lainnya diberikan metode Problem Based Learning $(P B L)$. Untuk variabel bebas yang lain yaitu variabel atribut potensi akademik siswa dijadikan sebagai variabel yang ikut mempengaruhi variabel terikat. Rancangan penelitian yang digunakan dalam penelitian ini adalah rancangan faktorial $2 \times 2$.

Desain penelitian ini menggunakan eksperimen desain faktorial dengan rancangan penelitian ini diperlihatkan pada tabel berikut:

Tabel 1. Desain Penelitian dengan Desain Faktorial

\begin{tabular}{|c|c|c|}
\hline Akademik Siswa & $\begin{array}{c}\text { Student } \\
\text { Teams-achievement } \\
\text { Division (STAD) } \\
\left(\mathrm{a}_{2}\right)\end{array}$ & $\begin{array}{c}\text { Problem Based } \\
\text { Learning (PBL) } \\
\qquad\left(a_{2}\right)\end{array}$ \\
\hline $\begin{array}{c}\text { Kemampuan Potensi } \\
\text { Akademik Tinggi } \\
\left(b_{2}\right)\end{array}$ & $a_{2}, b_{2}$ & $a_{2} b_{2}$ \\
\hline $\begin{array}{l}\text { Kemampuan Potensi } \\
\text { Akademik Rendah } \\
\left(\mathbf{b}_{2}\right)\end{array}$ & $a_{2} b_{2}$ & $a_{2} b_{2}$ \\
\hline
\end{tabular}

Keterangan :

$a_{1} b_{1}$ : Rata-rata hasil belajar siswa menggunakan pembelajaran dengan metode pembelajaran Student Teamsachievement Division (STAD) dengan Kemampuan Potensi Akademik Tinggi. $a_{1} b_{2}$ : Rata-rata hasil belajar siswa menggunakan pembelajaran dengan metode pembelajaran Student Teamsachievement Division (STAD) dengan Kemampuan Potensi Akademik Rendah $\mathrm{a}_{2} \mathrm{~b}_{1}$ : Rata-rata hasil belajar siswa menggunakan pembelajaran dengan metode pembelajaran Problem Based Learning $(P B L)$ dengan Kemampuan Potensi Akademik Tinggi. 
$\mathrm{a}_{2} \mathrm{~b}_{2}$ : Rata-rata hasil belajar siswa menggunakan pembelajaran dengan metode pembelajaran Problem Based Learning $(P B L)$ dengan Kemampuan Potensi Akademik Rendah.

Apabila hasil analisis varians menunjukan perbedaan hasil belajar antara variabel bebas dengan variabel terikat dan adanya interaksi antar variabel bebas dan variabel terikat, analisis dilanjutkan dengan uji lanjut untuk menguji hipotesis penelitian.

\section{HASIL PENELITIAN DAN PEMBAHASAN}

\section{Interaksi antara metode pembelajaran dengan potensi akademik siswa}

Dalam penelitian ini menemukan adanya interaksi antara metode pembelajaran dengan potensi akademik siswa dan pengaruhnya terhadap pencapaian hasil belajar siswa. Siswa dengan potensi akademik tinggi rata rata hasil belajarnya akan lebih maksimal apabila diajar dengan menggunakan metode pembelajaran $P B L$, namun metode $P B L$ kurang baik hasilnya apabila digunakan untuk mengajar siswa dengan potensi akademik rendah, ini dapat dilihat bahwa siswa yang mempunyai potensi akademik rendah nilai hasil belajar rata-rata jauh berbeda dengan siswa yang mempunyai potensi akademik tinggi apabila sama-sama diajar dengan metode $P B L$. Berbeda dengan metode $S T A D$, untuk siswa dengan potensi akademik rendah rata rata hasil belajarnya cenderung lebih baik dibandingkan siswa yang diajar dengan metode $P B L$ dengan potensi akademik rendah, namun untuk siswa dengan potensi akademik tinggi rata rata hasil belajarnya kurang maksimal apabila diajar dengan metode $S T A D$ karena cenderung masih lebih baik apabila diajar dengan metode $P B L$. Interaksi antara metode pembelajaran dengan potensi akademik siswa dapat dilihat pada diagram di bawah ini.

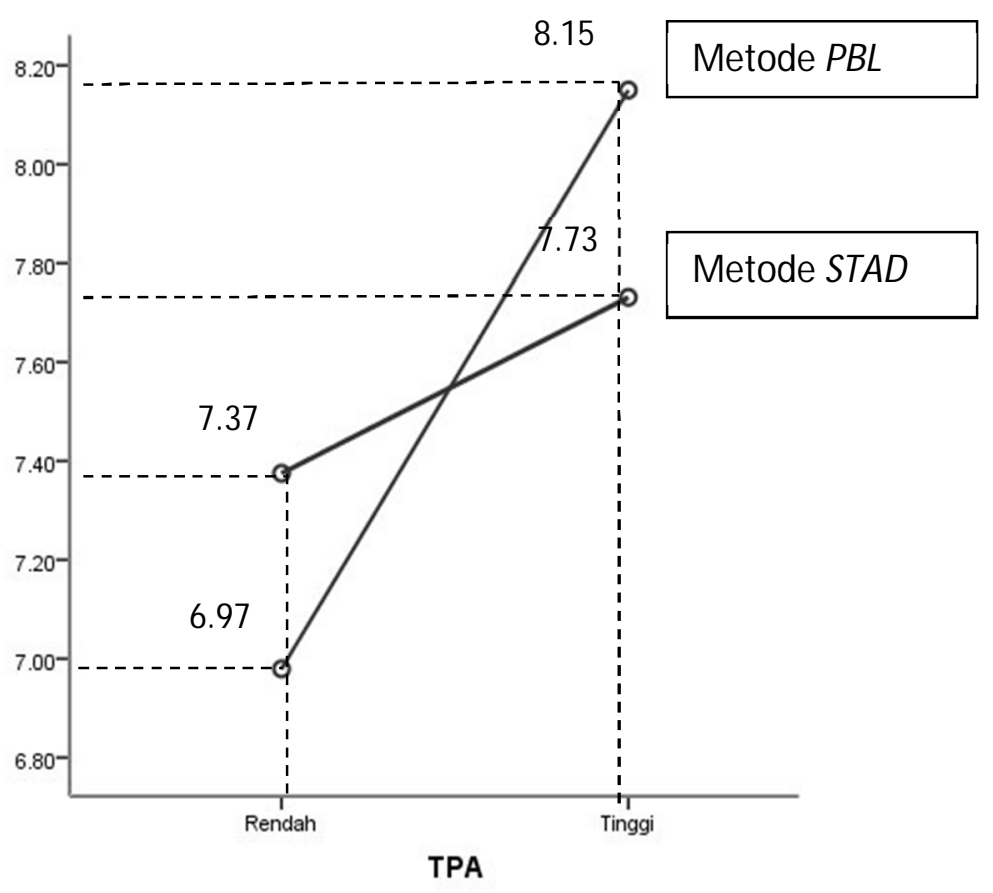

Gambar 1. Interaksi Antara Metode Pembelajaran dengan Potensi Akademik Siswa 
Hasil belajar kompetensi memelihara/servis sistem bahan bakar bensin antara siswa yang diajar dengan metode pembelajaran STAD dan yang diajar dengan metode $P B L$

Hipotesis dalam penelitian ini menyatakan tidak ada perbedaan hasil belajar siswa antara yang diajar dengan metode pembelajaran Student Teams-achievement Division STAD dan metode pembelajaran Problem Based Learning diterima. Hal ini menunjukan bahwa secara umum metode pembelajaran $S T A D$ dan $P B L$ tidak terdapat perbedaan apabila diterapkan pada pembelajaran kompetensi memelihara/servis sistem bahan bakar bensin.

Pada metode pembelajaran $S T A D$ siswa saling mendukung dan membantu satu sama lain dalam menguasai meteri yang di ajarkan guru secara singkat. Saat diberikan penugasan secara kelompok siswa terlihat cukup antusias dan memiliki motivasi yang tinggi dalam bekerja sama serta saling mengajarkan ke teman lain satu timnya untuk menjadi kelompok yang terbaik dalam satu kelas tersebut. Selain itu siswa lebih terlihat nyaman karena sifat pembelajaran lebih menyenangkan, aktif dan tidak monoton serta tidak merasa tertekan oleh guru di kelas.

Pada metode pembelajaran $P B L$ bersifat student centered seperti halnya pembelajaran $S T A D$, hanya yang membedakan dalam metode ini adalah pembelajaran berawal dari menggunakan masalah untuk belajar. Sebelum siswa mempelajari suatu hal, mereka diharuskan mengidentifikasi suatu masalah, baik yang dihadapi secara nyata, telaah kasus ataupun berbagai permasalahan dalam diri mereka. Masalah diajukan sedemikian rupa sehingga para siswa menemukan kebutuhan belajar yang diperlukan agar mereka dapat memecahkan masalah tersebut. Dari berbagai maslah yang telah ditemukan kemudian siswa merumuskan maslah tersebut dan mencari pemecahannya. Dalam pemecahan masalah dilakukan dengan diskusi kelompok sehingga siswa dapat saling bertukar pikiran dan membagi ilmu dengan siswa lainya. Setelah masalah dipecahkan dilanjutkan dengan presentasi kelas, dari presentasi ini akan terjadi diskusi dan pertukaran informasi kembali dalam kelompok satu kelas. Dari diskusi itu akan didapatkan pengalaman dan wawasan baru dan kadang ditemukan juga permasalahan permasalahn baru yang berkaitan untuk dipecahkan. $\quad P B L$ merupakan model pembelajaran yang berorientasi pada kerangka kerja teoritik konstruktivisme. Dalam karangka konstruktivisme siswa dapat merefleksikan pengalaman dan lebih menekankan pada aktivitas siswa yang akan menjadikan siswa lebih banyak berinteraksi dengan objek dan peristiwa, sehingga siswa memperoleh pemahaman, peran guru hanya sebagai fasilitator bukan pentransfer pengetahuan.

Perbedaan hasil belajar kompetensi memelihara/servis sistem bahan bakar bensin antara siswa yang mempunyai kemempuan potensi akademik tinggi dan rendah

Hipotesis dalam penelitian ini menyatakan ada perbedaan hasil belajar antara siswa yang mempunyai kemampuan potensi akademik tinggi dan rendah diterima. Seperti penjelasan sebelumnya bahwa siswa dengan kemampuan potensi akademik tinggi akan lebih cakap dan mampu dalam menerima materi dibandingkan dengan siswa yang mempunyai potensi akademik rendah. Dari hasil penelitian 
terbukti bahwa dari kedua metode pembelajaran yang diberikan baik metode $S T A D$ maupun $P B L$ memberikan temuan hasil yang sama yaitu siswa yang mempunyai kemempuan potensi akademik tinggi cenderung mempunyai rata - rata nilai yang lebih baik dibandingkan dengan siswa yang mempunyai potensi akademik rendah. Ini dikarenakan siswa yang mempunyai kemampuan potensi akademik tinggi cenderung lebih aktif dalam berdiskusi sehingga mereka lebih memiliki wawasan yang lebih luas dan mampu membangun suasana yang kondusif dan membuat berjalanya diskusi lebih maksimal. Dengan keaktifan tersebut maka akan berdampak pada hasil, pengetahuan dan pengalaman belajar yang mereka dapatkan.

Perbedaan hasil belajar siswa yang diajar dengan metode Student Teams-achievement Division STAD antara siswa yang mempunyai kemampuan potensi akademik tinggi dan rendah

Hipotesis dalam penelitian ini menyatakan tidak ada perbedaan hasil belajar siswa yang diajar dengan metode Student Teams-achievement Division STAD antara siswa yang mempunyai kemampuan potensi akademik tinggi dan rendah diterima. Ini berarti pada pembelajaran dengan mengunakan metode STAD tidak ada perbedaan rata-rata hasil belajar yang signifikan antara siswa yang mempunyai kemampuan potensi akademik tinggi dan rendah. Hal ini dikarenakan pada pendekatan pembelajaan dengan metode STAD siswa dikelompokan dalam tim-tim pembelajaran dengan anggota yang beragam. Pada pembelajaran dengan metode $S T A D$ mempunyai konsep utama yaitu untuk saling memotivasi siswa agar memberi semangat dan saling membantu dalam menyelesaikan tugas yang diberikan. Selama belajar tim, tugas anggota tim adalah menuntaskan bahan ajar yang dipresentasikan dan membantu teman sesama tim menuntaskan bahan ajar. Apabila siswa menginginkan tim mereka mendapatkan penghargaan tim, mereka harus saling membantu. Dari konsep tersbut maka akan terjadi saling ketergantungan antara siswa dalam satu tim ditambah dengan adanya motivasi untuk mendapatkan penghargaan yang akan diberikan. Dengan saling ketergantungan tersebut maka baik siswa yang memiliki kemampuan potensi tinggi dan rendah akan menjadi termotivasi untuk bekerja sama dan tentunya saling membantu untuk memenangkan prestasi dalam timnya.

Perbedaan hasil belajar siswa yang diajar dengan metode Problem Based Learning antara siswa yang mempunyai kemampuan potensi akademik tinggi dan rendah

Hipotesis dalam penelitian ini menyatakan ada perbedaan hasil belajar siswa yang diajar dengan metode Problem Based Learning antara siswa yang mempunyai kemampuan potensi akademik tinggi dan rendah diterima. Ini berarti pada pembelajaran dengan mengunakan metode $P B L$ terdapat perbedaan rata-rata hasil belajar yang signifikan antara siswa yang mempunyai kemampuan potensi akademik tinggi dan rendah. Hal ini dikarenakan metode $P B L$ mempunyai konsep pemecahan masalah dengan diskusi kelompok dengan konsep sedikit bebeda daripada metode STAD. Pada pembelajaran dengan metode $P B L$ tidak terdapat ketergantungan tim seperti halnya metode $S T A D$, sehingga diskusi pada metode $P B L$ lebih menekankan pada pertukaran 
pendapat dan berbagi pengalaman dalam pemecahan masalah. Dalam metode $P B L$ tidak terdapat penghargaan tim sehingga tidak ada ketergantungan antara anggota tim untuk untuk menjadi tim yang terbaik. Ini akan cenderung membuat siswa yang pasif dalam berdiskusi akan mempunyai pengalaman belajar yang kurang karena kurang adanya motivasi saling membantu antar anggota tim. Pada metode $P B L$ sangat baik dalam menelusuri dan meng-explor pengetahuan, ini dikarenakan saat pemecahan masalah bisa ditemukan suatu hal yang baru sehingga merangsang keinginan untuk mengetahui hal tersebut.

\section{SIMPULAN}

Berdasarkan data dan hasil pembahasan tentang Pengaruh metode pembelajaran Student Teams-achievement Division (STAD) dan Problem Based Learning (PBL) ditinjau dari potensi akademik siswa yang diperoleh pada penelitian ini dapat disimpulkan sebagai berikut:

1. Secara keseluruhan hasil belajar Memelihara/Servis sistem bahan bakar bensin, antara siswa yang diajar dengan metode pembelajaran $S T A D$ dan $P B L$ tidak terdapat perbedaan. Dari hasil ini dapat dikatakan bahwa kedua metode tersebut secara umum mempunyai pengaruh yang sama terhadap peningkatan hasil belajar.

2. Secara keseluruhan hasil belajar Memelihara/Servis sistem bahan bakar bensin, antara siswa yang mempunyai kemampuan potensi akademik tinggi dan rendah terdapat perbedaan. Dari hasil ini dapat dikatakan bahwa siswa yang mempunyai potensi akademik tinggi cenderung mempunyai nilai rata-rata hasil belajar yang lebih baik dari pada siswa yang mempunyai potensi akademik rendah.

3. Secara keseluruhan hasil belajar Memelihara/Servis sistem bahan bakar bensin siswa yang diajar dengan metode STAD antara siswa yang mempunyai kemampuan potensi akademik tinggi dan rendah tidak terdapat perbedaan. Dari hasil ini dapat dikatakan bahwa metode belajar STAD baik diaplikasikan untuk siswa yang mempunyai kemampuan potensi akademik tinggi dan rendah.

4. Secara keseluruhan hasil belajar Memelihara/Servis sistem bahan bakar bensin siswa yang diajar dengan metode $P B L$ antara siswa yang mempunyai kemampuan potensi akademik tinggi dan rendah terdapat perbedaan. Dengan menggunakan metode $P B L$ siswa yang mempunyai potensi akademik tinggi cenderung mempunyai nilai rata-rata hasil belajar yang lebih baik dari pada siswa yang mempunyai potensi akademik rendah. Dari hasil ini dapat dikatakan bahwa metode belajar $P B L$ akan lebih baik apabila diaplikasikan untuk siswa yang mempunyai kemampuan potensi akademik tinggi dan tidak cocok untuk siswa yang mempunyai kemampuan potensi akademik rendah .

5. Terdapat interaksi antara metode pembelajaran STAD dan PBL terhadap Potensi Akademik Siswa dan pengaruhnya terhadap pencapaian hasil belajar Memelihara/Servis sistem bahan bakar bensin. Dari temuan ini dapat disimpulkan bahwa siswa yang mempunyai kemempuan 
potensi akademik tinggi hasil belajarnya akan lebih maksimal apabila diajar dengan metode $P B L$, namun sebaliknya siswa yang mempunyai kemempuan potensi akademik rendah hasil belajarnya akan lebih maksimal apabila diajar dengan metode STAD. Dari hasil tersebut secara umum dapat disimpulkan bahwa untuk mendapatkan hasil belajar lebih maksimal perlu memilih metode belajar yang sesuai, serta melihat kemampuan potensi akademik yang dimiliki siswa.

\section{DAFTAR PUSTAKA}

Amir, M Taufiq. 2010. Dasar-dasar proses belajar mengajar. Bandung: Grasindo.

Anonim. 2012. Peran dalam pengukuran dan evaluasi. Diambil pada tanggal 18 Mei 2012, dari http://episentrum.com/ artikelpsikologi/peran-dalam-pengukuran-danevaluasi

, 2012. Psychological Test. Diambil pada tanggal 18 Mei 2012, dari http://www.enotes.com/psycological-testreference
Dittrich, Joachim et al. 2009. Standardisation in TVET teacher education. Alle Reche vorbehalten: Peter Lang $\mathrm{GmbH}$.

Finch, Curtis R. \& Crunkilton, John R. 1999. Curriculum development in vocational and technical education. planning, content, and implementation. Sidney: Allyn and Bacon Inc.

Glazer, E. 2001. Problem based instruction from emerging perspectives on learning, teaching and technology. Diambil pada tanggal 8 Mei 2012, dari http://www.projects.coe.uga.edu/epltt/ind ex.php?title=Problem_based_instruction

Ibnu Hajar 2010. Cukup 5 jam memehami Psikotes dan TPA. Yogyakarta: Buku Biru.

Sanjaya, Wina. 2007. Strategi pembelajaran berorientasi standar proses pendidikan. Jakarta: Kencana Prenada Media.

Slavin, Robert E. 1995. Cooperative learning: theory, research and practise. Boston: Allyn and Bacon.

Slavin, Robert E. 2010. Cooperative learning teori riset dan praktek. Bandung: Nusa Media.

Sugihartono, dkk. 2007. Psikologi pendidikan. Yogyakarta. UNY Press.

Suyono dan Hariyanto. (2011). Belajar dan Pembelajaran. Bandung : PT. Remaja Rosdakarya. 